Historic, Archive Document

Do not assume content reflects current scientific knowledge, policies, or practices. 
RETUP 1 POMOLOGY

SECTION TIPMENCLATUM

Paper Shell Pecans

How To Grow Them * AUG 241920

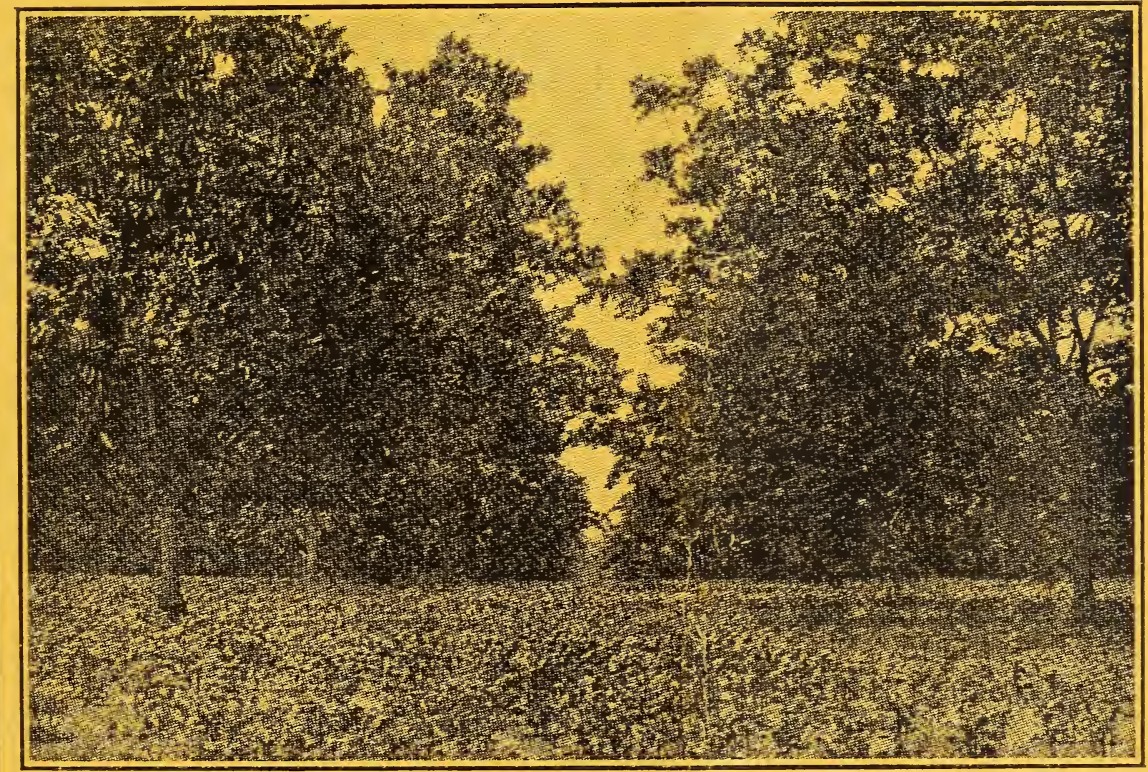

A 14 YEAR OLD PECAN GROVE

\section{Texas Pecan Nursery}

R. W. FAIR, Manager

Arp, Texas 



\section{HIOW IOO GIIOW}

\section{Paper Shell Pecams}

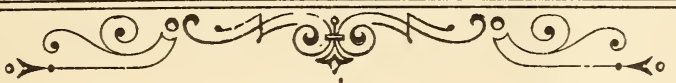

nensw

We Grow

Pecans Exclusively.

\section{Wwisy}

Send us

Your Orders.

\section{mins}

We will

Treat You FAIR.
GOVERNOR HOGG'S REQUEST AT HIS DEATH WAS, THAT INSTEAD OF PLACING A MONU. MENT AT MY GRAVE, SET OUT A PECAN TREE AND LET THE NUTS FROM THIS TREE BE DISTRIBUTED A MONG THE SCHOOL CHILDREN OF TEXAS TO BE PLANTED, AND LET TEXAS BE A LAND OF PECANS.

wouns

Texas Pecam Nuritery R. W. FAIR, Mgr. :-: ARP. TEXAS 


\section{Introductory}

For several years I have been studying the pecan proposition carefully, and I find it becomes more interesting each day. As time passes greater opportunities are being offered to everyone that's willing to take hold of the pecan business and say, "That I will succeed regardless of whatever obstacle confronts me." It of course requires a few years of patient waiting, but great is the reward to the one who waiteth. 


\section{How to Grow Paper Shell Pecans}

We have a large number of inquiries asking "how to grow pecans," so we are giving our experience and the experience of some of the oldest pecan men in the South. So if the large number of people that are in. terested in pecans will follow the following instructions carefully, success will be sure. We will treat every subject of the pecan as it comes:

\section{Location}

The following States are the best adapted to the pecan growing: Texas, Louisiana, Mississippi, Georgia and Oklahoma. There are, of course, pecans growing and doing nicely, in a few other Southern States but these are the main States. We believe that Texas is the greatest pecan State there is. There are thousands and thousands of acres of Texas lands that are covered with large, stately pecan trees, in fact, some of these trees measure 75 feet high and have a spread of about 70 feet. This tree bears from 1000 to 1300 pounds of nuts per year. Texas produces over half of the seedling pecans. Why cant she produce the same amount of paper shell pecans? We have the same chance to lead in this industry that we have to lead in raising cotton. There are other States that are greatly in advance of us in growing paper shell pecans, but all Texas needs is for her people to become better acquainted with the great future that lies in the pecan industry, and then we will produce pecans in the same proportion that we produce cotton today. 


\section{Suitable Soils for Pecans}

Pecans do best on land where you can find water from 10 to 30 feet deep. However, I know of some pecan trees that are very large and old which bear well where it is 50 feet to the water. Be sure not to plant pecan trees in sour land or land that is not drained. Often this kind of land can be well ditched and made a fine place for your grove. Land that will grow good cotton or corn, etc., will produce a good grove. Rich bottom land is as a rule fine for pecans, but often the upland will produce almost as well. Use land that can be cultivated in some kind of crop.

\section{Preparation of Soil}

Be sure to have your land thoroughly broken and harrowed. It will be best to subsoil your land before breaking and this will deepen the soil and cause it to hold moisture much better.

\section{Time to Set Out Grove}

The time to begin setting out pecan trees is about Nov. 1st, as we have most always had good fall rains and enough cool weather to cause sap to go down and trees to shed their leaves. Trees can be set from Nov. 1st until March 15. I prefer setting trees as early as possible so the winter rains will get the dirt more thoroughly packed around roots; however, you can get good results in Jan. and Feb., and some recommend planting as late as April 1.

\section{Distance to Plant Trees}

It's altogether what kind of land that is going to be set. Very rich land should have from 15 to 20 trees per 
acre. Medium land should have from 20 to 25 and thin land should have from 25 to 30 trees per acre. All of this land shouid be fertilized, but the poorer the land the more you should use. Some recommend planting trees twice as close as they should be when they get large, and when they become crowded have every-otherone cut out. By doing this any one can get the benefit of all the trees for a number of years.

\section{Buying Trees}

Pecan trees are like anything else, you can buy the kind of trees you want. If anyone wants a cheap tree they can be found, but you can not expect much when you get them. When anyone plants pecan trees he wants the best regardless of price. It costs the nurseryman much more to raise first-class trees than it does to raise runts. WE RAISE THE BEST.

\section{Digging Holes}

Holes should be dug from 30 to 36 inches in width or depth. The top soil should be put in one pile and the clay or bottom soil in another. Its often best to blow the holes with dynamite. In most cases one half of a stick is sufficient but in a few cases a whole stick should be used. This of course loosens the ground thorough. ly which will cause the roots to take hold much faster and the ground will hold the moisture better.

\section{Planting Trees}

First upon receiving your trees be sure to protect them from the sun, wind or from being frozen. Plant at once and be sure to keep them wet until planted. 
See that all roots have been cut off smoothe; place tree in hole and fill up hole or dig deeper so the tree will be in the ground about one inch deeper than it came out. Arrange roots in proper shape and put dirt aroud them and pack it carefuly to prevent skinning the roots. Fill around tree with rich top soil until about two-thirds full, then pour in one or two buckets of water owing to moisture in ground. This water also helps to settle the dirt around the roots, which is very important. One of the very impotant points in growing pecans is to set your trees out in a first-class way.

\section{Cultivation}

As I have already said, be sure to have your land in good condition before planting. Plant this grove in something that requires good cultivation. Plant some crop that will not grow large as it will shade and sap your trees; cotton, peas, potatoes, peanuts and all kinds of truck or small plants will be fine. Corn can be planted if plenty of room is given on each side.

Unless you are sure you have a very careful hand to work your trees I would recommend driving two good stakes about twelve or eighteen inches from tree on each side to prevent these trees from being skinned by horse, swingletree and plow. These stakes should be from three to four feet high.

Cultivate your pecan grove like a garden and in a few years it will let you sit back in a chair of ease and it will take care of you the rest of your days. 


\section{Fertilizing}

This subject is very important as it is very neccessary to get the largest tree in the shortest time, so it will be large enough to bear profitably. Make your land rich for other crops. Stable manure or cotton seed meal is fine. A good formula for growing trees is 8 per cent acid, 4 per cent ammonia and 4 per cent potash. This should be scattered around tree and dug or plowed in First year use about 2 pounds to each tree of cotton seed meal or of the above formula, second year 4 pounds, third year 6 pounds, fourth 8 pounds, fifth year 10 pounds. For different soils this can be increased or decreased. When trees begin bearing they need more potash and less nitrogin.

Be careful not to let the fertilizer come into direct contact with the roots as this is very injurious to the tree. It should be applied close around the tree while small and mixed throughly with the soil and as the tree grows the fertilizer should be scattered out to the end of the limbs and plowed under. As has been said be sure to fertilize and cultivate your grove well, so when bearing age comes the tree will be large and thrifty and will be able to repay you a thousand times for your trouble.

Bearing Age

The first question most people ask when pecans are mentioned is when will they bear.

It was once an idea amoung our older people that it took a pecan tree fifteen years to bear, but the coming of the budded paper shell pecans has long since exploded that idea.

We have a number of trees in our nursery that were 
budded in April and in May had clusters of pecans on them. We have other trees transplanted two years ago and have from 12 to 50 nuts per tree. Anyone buying our trees if properly cared for should begin to have some nuts in two years and all should bear in four years.

It is not a tree that bears earlist that you want, but one that will grow fastest, a pecan grove will not bear profitable crops before the fifth or sixth year. A pecan grove will not bring an income for first five years, except from crop planted in between trees. Then for one or two years it will pay about the same as any other crop on same land. After the seventh or eight year it will become more profitable each year. You will scarcely miss the ground trees take for four to five years. Pecan trees live for centuries and increase in crops each year.

\section{What Will a Pecan Grove Pay?}

This is a subject we areall instructed in which will be governed entirely with the care given the trees. A well cared for grove will be an asset that anyone will be proud of, but if you are not willing to give your trees a medium showing, you had better not plant them.

A pecan grove put out in first class condition on land that cost say $\$ 25$ per acre is valued at $\$ 100$ per acre the first year. Each year it is estimated that the growth will increase the value $\$ 100$ per acre until they are ten years old. This making them worth $\$ 1000$ per acre.

Here are a few figures for your consideration which will easily prove to you that an acre of paper shell pecans is worth $\$ 1000$ and up if they have had proper care. 
There are a great many capitalists that figure that if they buy a piece of property that pays them $\$ 100$ that property is worth $\$ 1000$ which would be 10 per cent. You can value an acre of pecans at $\$ 1000$, and when it is from 12 to 15 years old it will pay from 25 to 30 per cent on that valuation.

Mrs T. D. Ramsey, of Albany, Georgia, has an 80 acre pecan grove which she has been offered $\$ 80,000$ for at 12 years old, but she refused to sell it and gave for her reason that there was nothing she could invest her money in that would bring her such an income and at the same time be so safe for her children as the pecan grove. (A wise decision.)

There is another in Georgia that refused $\$ 20,000$ for an eleven acre grove.

Col. C. A. Van Duzee, President of the National Nut Growers Association, said: My own best trees are eight years old now and they have returded me more money than the cost of trees, land cultivation, fertilizing and interest on investment. He says he values his grove at ten times what it cost.

Mr.C. M. Barnwell, of Baconton, Georgia sold his young grove for $\$ 200,000$. He can not give up the pecan business so he has begun another grove of 400 aeres.

Mr. I. P. Delmas, Pascagoula, Miss., has an 18 acre grove which contains 325 trees of four varieties and when this grove was only nine years old he gathered 9750 pounds of pecans from it. He sold these nuts at 75c, 60c and 40c per pound. Say he averaged 50c per pound, the crop for one year paid him $\$ 4875$ or $\$ 270$ per acre and $\$ 15$ per tree. This 18 acre grove would pay 10 per cent on $\$ 48,750.00$ and each acre would pay 10 per cent on $\$ 2,700.00$ and each tree would pay 10 per cent 
on $\$ 150.00$ As stated before this grove was only nine years old. You might say just begining to bear. At twelve and fifteen years old it will double and trebble the above crop, and will continue to increase yield every year as long as they live, and there are lots of pecan trees that's know to be over a hundred years old and is still bearing heavy crops. Think and see if you remember of seeing many large PECAN TREES DEAD. Now the above grove has had good attention but no better than we can give if WE WILL. Let's make a conservitive estimate and cut the above figures one half and figure on 20 trees per acre at 5.50 per tree one acre would bring $\$ 150$ which would be 10 per cent on $\$ 1500$ Remember we are figuring on young trees but wouldn't they be worth $\$ 1000$ per acre if they never increased any more. A pecan grove will continually increase in value as the trees grow larger. At twelve years they should double the above yield and at fifteen or twenty years they should double what they did at twelve years.

An article appeared in Home and State of Dallas, November 15-'14, said every home in the pecan district should have at least 25 to 30 good pecan trees set out around the yard, barnyard, cow lot, hog pens, and fence corners. All of these places are fine if the trees are cultivated and started off growing nicely In many cases pecan trees bear from 200 to 600 pounds of pecans per tree and are readily sold at from 40 to $60 \mathrm{c}$ per pound. Twentyfive or thirty trees producing one half of the above crop and selling at one fourth the above price would add some $\$ 750$ to $\$ 900$ to the income from the farm.

Mr. John A. Lott, of Waycross, Georgia, has a four acre seedling grove which produced 5,000 pounds pecans 
one year and were sold at $\$ 1,275$ which was $\$ 318.75$ per acre or would have been 10 per cent on $\$ 3,187.50$. Are not these trees worth $\$ 1,000$ per acre?

\section{Some Records of Individual Trees}

The following telegram was sent to the Secretary National Nut Growers Association at Houston, November 5th to 7 th 1913 . The object of message is to advise that on November 3rd we gathered from one tree thirteen years old 235 pounds of Delmas pecans. This we consider the record Don't know just what these nuts sold for but not less than 50c per pound. This crop from one tree brought $\$ 117.50$. This tree is owned by Delmas \& Son at Pascogoula, Miss.

K. Powell of Cairo Georgia has a seedling tree that he has sold for the last three years an average of $\$ 100$ worth of pecans per year from it.

J. B Wright of Cairo, Georgia, has one Frotscher (budded) tree that is about twenty-three years old that has borne 1,563 pounds of nuts in the last six years. These nuts sold for over $40 \mathrm{c}$ per pound. This one tree in six years paid him $\$ 62520$. How is that?

This is the oldest budded tree I know of.

There is a pecan tree on the banks of the river near Toledo, Texas, that bore one crop of 1,300 pounds of nuts, and if they were sold at 10c per pound this one tree paid $\$ 130$ in one year. This tree measured 12 feet 8 inches in circumference four feet from the ground. It is 78 feet high and its limbs spread 71 feet. There are hundreds and thousands of seedling trees all over Texas that bear from 200 to 1,000 pounds of nuts per year. Some FEw trees have been known to bear one ton of nuts per year, but these are very scarce. 
The Department of Agriculture in Bulletin No. 2 says that a man can plant a pecan grove and cultivate the land in other crops as he has been doing and at the same time be developing his pecan grove that will be worth from $\$ 1,000$ to $\$ 2,000$ per acre.

Every man that owns his home should set out from one to ten acres in pecans by all means.

The figures that I have given are from good trees and groves and of course can not be used to base figures for the medium grove but, you can make a very conservative estimate and you will find that there will be, after a few years to the man that sets out five acres a good easy living, and the man that sets out 10 acres an easy living and a good bank account. The man that sets out a hundred acre grove will have a fortune.

\section{Overproduction}

Some people seem to think that there is danger of producing too many pecans BUT I SAY NO and will give my reason. There is first only a few Southern states that raise pecans, and of course there are people living in the best pecan districts that will not plant them because they never look further than a year ahead of them, and are not willing to to wait from five to seven years. Another man owning a hundred acres of good land will not put out over 10 acres in pecans.

Pecans are not like peaches and most fruits which have to be gathered, sold and eaten or canned in one week's time We would have never had an overproduction of peaches notwithstanding the millions of aores that are set out, if we had twelve months to sell our crop in.

We have twelve months to dispose of our pecan crop. After the United States has been well supplied pecans 
can be shipped to any country in the world. There are comparatively few people that really know what pecans are. Pecans are becoming very popular for table use.

There are now several large hulling machines and the pecan meats are sold at a fancy price for making can. dies etc. One company gave an order for 220,000 pounds of pecans after being hulled.

The pecan makes a very fine grade of oil which will be used for cooking and table use.

As a food there are very few things that furnish more food value or strength than does the pecan and this fact is becoming known better each year.

The pecan growers are advertising their products and are teaching the people its great value as a food product.

\section{Pecans vs Insurance}

It has often been said that it would be better for a man to leave his wife and children a 10 acre pecan grove in good condition, than to leave them a $\$ 10,000$ in. surance policy. As the old saying goes riches (money) takes wings and flies. This insurance money can be used very carefully but as a rule it's soon gone, and several children left for the mother to provide for. There are so many trades that look good at first but later the judgment of men and women proves a failure. In many cases the insurance money has been lost in this way.

If a pecan grove has been left, it will bring a regular income increasing each year. As has been stated a pecan grove increases in value each year as the trees get older. The money from the pecans is not all turned 
at one time but it comes once a year and at the same time the grove remains and is in better condition each year as time rolls on.

\section{Pecans vs Cotton}

The farmer as a rule plants all the cotton that he and his family can work. They are forced to work many times from the earliest moment the sun rises to a very late hour at night. Oftentime they have toiled very hard and have fair prospects, a drouth, the army worm or boll wevil will come along and destroy most all of the crop. It is said that it costs $10 \mathrm{c}$ per pound to raise cotton. When it has to be sold for 6 to 8 cents per pound, where is the farmer getting any pay for the days, weeks and months that he and his family have been toiling to produce this cotton?

Instead of planting so much cotton every farmer that owns his home should plant 5,10 or 25 acres in pecans, or more if he can care for them instead of so much cotton. Pecans can be grown in your cotton field. Will require but little room until they begin bearing, and when they do begin bearing instead of a man and his family having to wear their lives out in cultivating and gathering the cotton the pecan grove will have to have a few plowings and harrowings. Then when fall comes go pick up your nuts and sell them if the price is right or keep them as long as you wish.

Set Out Pecan Trees for Shade Trees

I find that in many cases the people in the cities, towns and on the farms are putting out pecan trees for shade trees. This is a very wise idea, because 
there isn't any tree that makes a prettier shade tree than a pecan. It grows to be very large in every way and has a most beautiful shape. Besides its beauty, a few of these trees will add much in the way of food and cash. Why plant trees that will never be of any service except for shades. One good pecan tree will often pay from $\$ 25.00$ to $\$ 50.00$ per tree, and you may say will never die.

\section{Varieties}

We grow the following varieties which we consider best: Stuart, Van Demon, Schley, Frotscger, James, and Russell. The Stuart pecan is considered by all the one, that is, I feel safe in saying that 50 per cent of the pecans planted are of this variety, so to meet the demand our stock runs heavy of it. We grow five other varieties which are the best that there is.

\section{Our Nursery}

We have the largest Paper Shell Pecan in this part of the South, and it's our intentions to grow the very best pecan trees that can be grown. We believe in quality first.

We have for sale now, for this fall and winter delivery, some of the nicest trees we ever saw grow. These trees were budded in April on two year old roots and in forty-five days several of these buds had put out, bloomed and had several little pecans on them. The buds on our trees have made a growth of from one to six feet. This shows that our trees are very healthy.

We have the best root system (which is very important) by 50 per cent that I ever saw. All who have seen them will testify to this fact. These trees are 
grown in soil that produces a large number of large latteral roots.

\section{Buy Texas Grown Trees}

If you are going to buy pecan trees give us a chance. You will find it much better to buy Texas grown brees than to buy them from some other state where the climate and soil is different. You can get your trees from us and have them in the ground again before they come from other states.

\section{Prices on Our Trees}

Our prices are not on runty stock but on gond thrifty trees that will, with the root system they have, give excellent satisfaction.

Our prices are as low as you can expect to get first class trees for It costs more for a nursery now to grow large thrifty trees than it does to grow small shabby ones.

If you are going to buy pecan trees be sure to buy good ones. This is the first step to success in planting pecans.

\begin{tabular}{l|l|l|l|l}
\hline \multicolumn{1}{c|}{ TREES } & LOTS of 1 & 25 & 100 & 1000 \\
\cline { 1 - 2 } 1 to 2 feet & .65 & .60 & .50 & .40 \\
2 to 3 “ & .70 & .65 & .60 & .50 \\
3 to 4 ، & .85 & .80 & .75 & .70 \\
4 to 5 ، & 1.00 & .90 & .85 & .80 \\
5 to 6 ، & 1.25 & 1.15 & 1.00 & .95 \\
\hline
\end{tabular}

These Priees are all F. O. B Here 
No extra charges for packing and drayage.

All trees are guaranteed to be exactly true to name.

Our responsibility ends when trees are delivered to express company.

Terms: cash must be sent with each order or if C. O. D. shipments are wanted 25 per cent of amount must accompany order.

We especially solicit club orders. In many cases one can get several of his neighbors to go in with him and make an order together, and when this is done we will offer a club discount, provided as many as 50 trees or more is ordered.

Write us if there is anything you want to know about pecans.

As stated before we are making a special study of pecans and expect to keep up with the times on pecan subjects.

Send us your order and if you are pleased tell your neighbor and friends. Send their name and address and I will send a catalogue.

We thank all in advance who send us their orders, and wish them much success with pecans..

Yours for Business,

R. W. FAIR, Mgr.

TEXAS PECAN NURSERY.

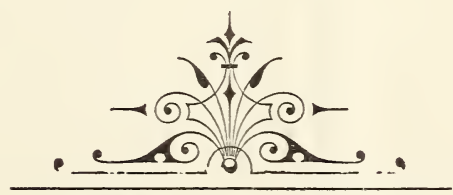

THE BANNER, PRINT

TROUP, TEXAS 

